\title{
PEMBUATAN APLIKASI KALKULATOR FINANSIAL PENDIDIKAN DAN PENSIUN PADA WEBSITE ALLIANZ.CO.ID DI PT GERBANG INDONESIA TEKNOLOGI
}

\section{(Creating of Education and Pension Financial Calculator Application on Allianz.co.id Website at PT Gerbang Indonesia Teknologi)}

\author{
FATIHATUL KHOMARIYAH ${ }^{1}$, BAYU WIDODO ${ }^{2}$, HANDRI PANGESTIAJI ${ }^{3}$ \\ 1 Sekolah Vokasi Institut Pertanian Bogor, Jalan Kumbang 14, Bogor \\ ${ }^{2}$ Sekolah Vokasi Institut Pertanian Bogor, Jalan Kumbang 14, Bogor \\ ${ }^{3}$ PT Gerbang Indonesia Teknologi, Ruko Bukit Cimanggu City Blok C2/14, Bogor \\ Email : fatiqha@gmail.com , bayuwi@apps.ipb.ac.id, handri.pangestiaii@gmail.com
}

\begin{abstract}
PT Gerbang Indonesia Teknologi is a technology and information service provider company. One of the services offered is web development. Allianz Indonesia is collaborating with PT Gerbang Indonesia Teknologi to develop its main website, Allianz.co.id. One of Allianz's services is an investment. The most important thing in achieving investment objectives is financial planning. Allianz created a calculation formula for compiling education and pension financial planning using the Microsoft Office Excel application. The problem is not everyone knows how to count using Microsoft Office Excel applications, and the calculation formula is quite complicated. Creating of education and pension financial calculator application is expected to help the community to analyze and prepare financial planning based on the needs of education costs and pension funds in the future, which can be accessed through the Allianz.co.id website.

The Creating of education and pension financial calculator applications applying the Scrum method. Scrum is suitable for use in creating this application because of the short processing time and the small number of teams. Scrum's activities include determining the product backlog, sprint, and demos. The creating of this application uses the Pimcore CMS based on the Symfony Framework.

Education and pension financial calculator application provides features for calculating the cost of education needed, calculating the investment in education costs needed, calculating the monthly living expenses in pension, calculating the pension funds needed, calculating the pension fund investment needed, and sending an email detailing the results of calculations.
\end{abstract}

Key words: calculator, education, pension, scrum, symphony

\section{ABSTRAK}

PT Gerbang Indonesia Teknologi merupakan perusahaan penyedia jasa layanan teknologi dan informasi. Salah satu jasa layanan yang ditawarkan yaitu web development. Allianz Indonesia bekerja sama dengan PT Gerbang Indonesia Teknologi untuk mengembangkan website utamanya yaitu Allianz.co.id. Salah satu layanan Allianz yaitu investasi. Hal yang terpenting 
untuk mencapai tujuan investasi salah satunya melakukan perencanaan finansial. Allianz membuat formula perhitungan untuk menyusun perencanaan finansial pendidikan dan pensiun menggunakan aplikasi Microsoft Office Excel. Permasalahannya tidak semua orang mengetahui cara menghitung menggunakan aplikasi Microsoft Office Excel dan formula perhitungannya cukup rumit. Pembuatan aplikasi kalkulator finansial pendidikan dan pensiun diharapkan dapat membantu masyarakat untuk menganalisa dan menyusun perencanaan finansial berdasarkan kebutuhan biaya pendidikan dan dana pensiun di masa depan, yang dapat diakses melalui website Allianz.co.id

Pembuatan aplikasi kalkulator finansial pendidikan dan pensiun menerapkan metode scrum. Scrum cocok digunakan dalam pembuatan aplikasi ini karena waktu pengerjaan yang singkat dan jumlah tim yang sedikit. Kegiatan scrum meliputi penentuan product backlog, sprint, dan demo. Pembuatan aplikasi ini menggunakan CMS Pimcore dengan basis Symfony Framework.

Aplikasi kalkulator finansial pendidikan dan pensiun menyediakan fitur untuk kalkulasi biaya pendidikan yang dibutuhkan, kalkulasi investasi biaya pendidikan yang dibutuhkan, kalkulasi biaya hidup bulanan pada masa pensiun, kalkulasi dana pensiun yang dibutuhkan, kalkulasi investasi dana pensiun yang dibutuhkan, dan kirim email rincian hasil kalkulasi.

Kata kunci: kalkulator, pendidikan, pensiun, scrum, symfony

\section{PENDAHULUAN}

PT Gerbang Indonesia Teknologi merupakan perusahaan penyedia jasa layanan teknologi dan informasi. Salah satu jasa layanan yang ditawarkan yaitu web development. Saat ini PT Gerbang Indonesia Teknologi mempunyai 15 klien, salah satu kliennya yaitu Allianz. Allianz bekerja sama dengan PT Gerbang Indonesia Teknologi sebagai penyedia jasa layanan teknologi dan informasi untuk mengembangkan website utama Allianz Indonesia yaitu Allianz.co.id.

Allianz merupakan perusahaan jasa keuangan multinasional yang bisnis utamanya adalah asuransi. Salah satu layanan Allianz yaitu investasi. Hal yang terpenting untuk mencapai tujuan investasi salah satunya melakukan perencanaan finansial. Allianz membuat formula perhitungan untuk menyusun perencanaan finansial pendidikan dan pensiun menggunakan aplikasi Microsoft Office Excel. Formula yang dibuat meliputi formula untuk menghitung kebutuhan biaya pendidikan di masa depan, kebutuhan biaya hidup bulanan pada masa pensiun, kebutuhan dana pensiun, serta investasi biaya pendidikan dan dana pensiun yang dibutuhkan. Permasalahannya tidak semua orang mengetahui cara menghitung menggunakan aplikasi Microsoft Office Excel dan formula perhitungannya cukup rumit.

Berdasarkan latar belakang yang telah diuraikan di atas, maka dibuat aplikasi Kalkulator Finansial Pendidikan dan Pensiun yang tersedia pada website Allianz.co.id dengan tampilan yang user friendly sehingga mudah digunakan semua masyarakat. Aplikasi ini diharapkan dapat membantu masyarakat untuk menganalisa dan menyusun perencanaan finansial berdasarkan kebutuhan biaya pendidikan dan dana pensiun di masa depan, yang dapat diakses dimana pun 
dan kapan pun melalui website Allianz.co.id.

Tujuan dari Pembuatan Aplikasi Kalkulator Finansial Pendidikan dan Pensiun pada Website Allianz.co.id di PT Gerbang Indonesia Teknologi sebagai berikut:

Menyediakan fitur kalkulasi biaya pendidikan yang dibutuhkan.

Menyediakan fitur pengiriman rincian hasil kalkulasi melalui email.

\section{METODE PENELITIAN}

Pembuatan aplikasi Kalkulator Finansial Pendidikan dan Pensiun pada Website Allianz.co.id di PT Gerbang Indonesia Teknologi menggunakan metode Scrum. Scrum adalah kerangka kerja proses yang telah digunakan untuk mengelola pengembangan produk kompleks sejak awal tahun 1990-an. Scrum adalah sebuah kerangka kerja untuk mengembangkan, menghantarkan dan mengelola produk yang kompleks (Schwaber dan Sutherland 2017).

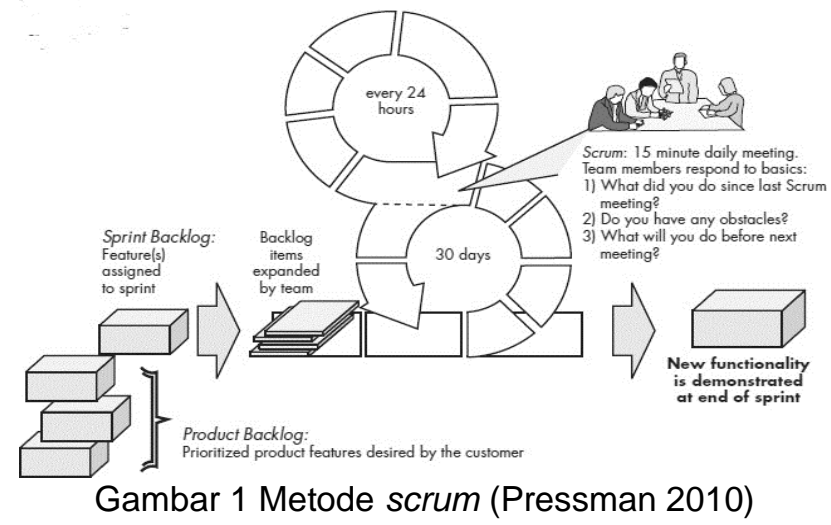

Tim scrum terdiri dari product owner, scrum master, serta tim pengembang. Product owner adalah orang yang bertanggung jawab untuk memaksimalkan nilai bisnis dari produk yang dihasilkan oleh tim pengembang. Scrum master adalah pemimpin tim scrum, bertugas untuk mengarahkan dan melatih tim pengembang. Tim pengembang terdiri atas para profesional yang bekerja untuk menghasilkan produk yang akan dirilis pada akhir sprint. Metode scrum terbagi atas tiga tahapan utama yaitu product backlog, sprint, dan demo.

\section{HASIL DAN PEMBAHASAN}

Pembuatan aplikasi Kalkulator Finansial Pendidikan dan Pensiun ini, terdiri dari tim scrum. Tim scrum terdiri atas product owner yaitu Handri Pangestiaji, scrum master yaitu M. Saeful Rizky, dan tim pengembang terdiri dari web \& graphics designer yaitu Asep Syaeful, programmer yaitu Fatihatul Khomariyah, dan quality assurance yaitu Yuni Faizah. Metode scrum terbagi atas tiga tahapan utama yaitu product backlog, sprint, dan demo. 


\section{$1 \quad$ Product Backlog}

Pada tahap penentuan product backlog diadakan pertemuan tim scrum. Kebutuhan-kebutuhan product owner dijabarkan dan diurutkan berdasarkan skala prioritas pada tabel product backlog. Tabel product backlog dapat dilihat pada Tabel 1.

Tabel 1 Tabel product backlog

\begin{tabular}{|c|c|c|}
\hline No & Deskripsi & $\begin{array}{c}\text { Skala } \\
\text { Prioritas }\end{array}$ \\
\hline 1 & Memahami struktur framework Symfony dan CMS Pimcore & 1 \\
\hline 2 & Perancangan, analisis, dan pemodelan sistem & 2 \\
\hline 3 & Implementasi database & 3 \\
\hline 4 & Visitor dapat menghitung biaya Pendidikan & 4 \\
\hline 5 & Visitor dapat masukan data diri kalkulator finansial pendidikan & 5 \\
\hline 6 & $\begin{array}{l}\text { Visitor dapat mengirim email rincian hasil kalkulasi biaya } \\
\text { pendidikan }\end{array}$ & 6 \\
\hline 7 & Visitor dapat melihat rincian hasil kalkulasi biaya pendidikan & 7 \\
\hline 8 & Visitor dapat menghitung investasi biaya pendidikan & 8 \\
\hline 9 & $\begin{array}{l}\text { Visitor dapat mengirim email rincian hasil kalkulasi investasi } \\
\text { biaya Pendidikan }\end{array}$ & 9 \\
\hline 10 & $\begin{array}{l}\text { Visitor dapat melihat rincian hasil kalkulasi investasi biaya } \\
\text { Pendidikan }\end{array}$ & 10 \\
\hline 11 & $\begin{array}{l}\text { Visitor dapat menghitung biaya hidup bulanan pada masa } \\
\text { pensiun }\end{array}$ & 11 \\
\hline 12 & Visitor dapat masukan data diri kalkulator finansial pensiun & 12 \\
\hline 13 & $\begin{array}{l}\text { Visitor dapat mengirim email rincian biaya hidup bulanan pada } \\
\text { masa pensiun }\end{array}$ & 13 \\
\hline 14 & $\begin{array}{l}\text { Visitor dapat melihat rincian biaya hidup bulanan pada masa } \\
\text { pensiun }\end{array}$ & 14 \\
\hline 15 & Visitor dapat menghitung total dana pensiun & 15 \\
\hline 16 & $\begin{array}{l}\text { Visitor dapat mengirim email rincian hasil kalkulasi total dana } \\
\text { pensiun }\end{array}$ & 16 \\
\hline 17 & Visitor dapat melihat rincian hasil kalkulasi total dana pensiun & 17 \\
\hline 18 & Visitor dapat menghitung investasi dana pensiun & 18 \\
\hline 19 & $\begin{array}{l}\text { Visitor dapat mengirim email rincian hasil kalkulasi investasi } \\
\text { dana pensiun }\end{array}$ & 19 \\
\hline 20 & $\begin{array}{l}\text { Visitor dapat melihat rincian hasil kalkulasi investasi dana } \\
\text { pensiun }\end{array}$ & 20 \\
\hline
\end{tabular}




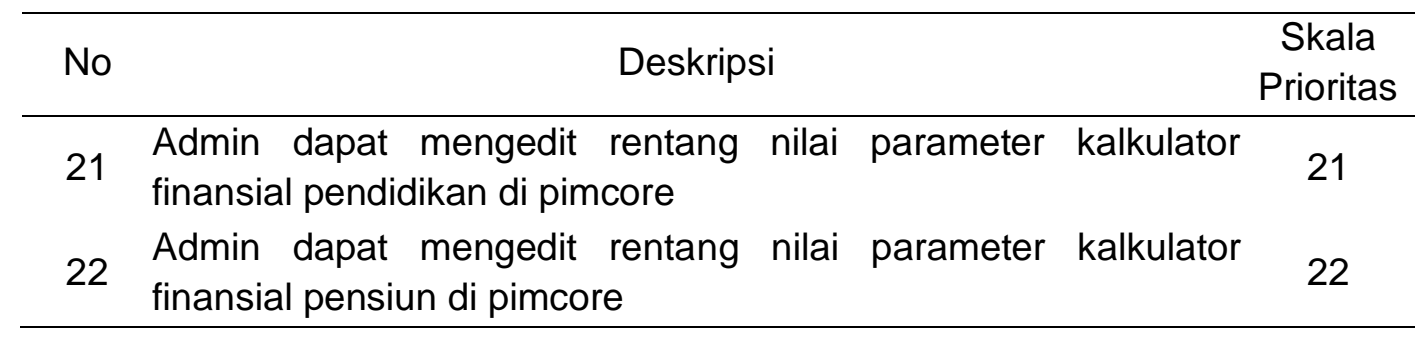

\section{Sprint}

Pembuatan aplikasi kalkulator finansial pendidikan dan pensiun dibagi menjadi dua kali sprint. Sprint pertama mengerjakan product backlog item point satu sampai sepuluh. Kegiatan sprint kedua yakni melanjutkan product backlog item sampai selesai.

\subsection{Sprint Pertama}

Pada sprint pertama dilakukan perancangan, analisis, dan pemodelan sistem. Fungsi yang dibangun pada sprint pertama yaitu fungsi-fungsi untuk kalkulator finansial pendidikan.

\section{A Sprint Planning}

Sprint planning merupakan acara pembukaan dalam rangkaian sprint. Proses sprint planning pada sprint pertama ini menetapkan sprint goal dan sprint backlog yang akan dikerjakan pada sprint pertama. Sprint backlog berisi sekumpulan backlog dan task yang harus dikerjakan oleh tim pengembang programmer. Sprint backlog pada sprint pertama mengerjakan product backlog item poin satu sampai sepuluh.

\section{B Daily Scrum}

Daily scrum pada sprint pertama di hadiri oleh tim pengembang dan scrum master. Acara ini dilakukan setiap hari dengan durasi 15-20 menit. Acara ini bertujuan untuk meninjau perkembangan sprint goal dan melakukan sinkronisasi pekerjaan masing-masing pada sprint pertama.

\section{Development}

Proses development pada sprint pertama mengerjakan sekumpulan task yang ada pada sprint backlog agar tercapai sprint goal pada sprint pertama. Berikut adalah pekerjaan yang telah dikerjakan tim pengembang programmer pada proses development :

1 Perancangan, analisis, dan pemodelan sistem

Pemodelan sistem menggunakan Unified Modelling Language (UML). Pemodelan sistem mencakup perancangan flowchart, use case diagram, class diagram, dan database structure.

a Flowchart

Alur keseluruhan aplikasi Kalkulator Finansial pendidikan dan Pensiun ini dibagi menjadi dua fase. Fase pertama menggambarkan alur penggunaan kalkulator finansial pendidikan dan fase kedua menggambarkan alur penggunaan 
kalkulator finansial pensiun. Flowchart fase pertama dapat dilihat pada Gambar 2 dan flowchart fase kedua dapat dilihat pada Gambar 3.

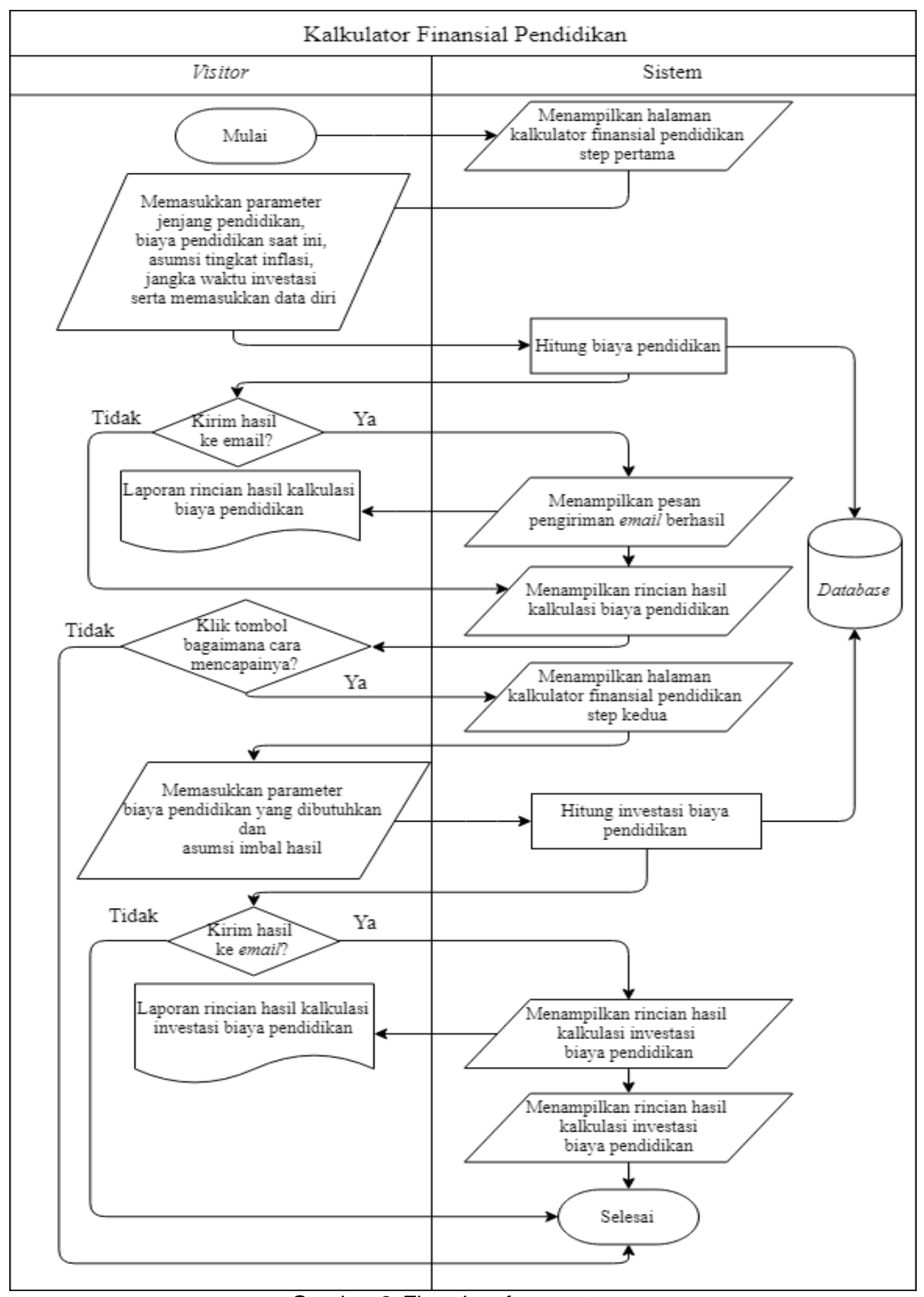

Gambar 2 Flowchart fase pertama 


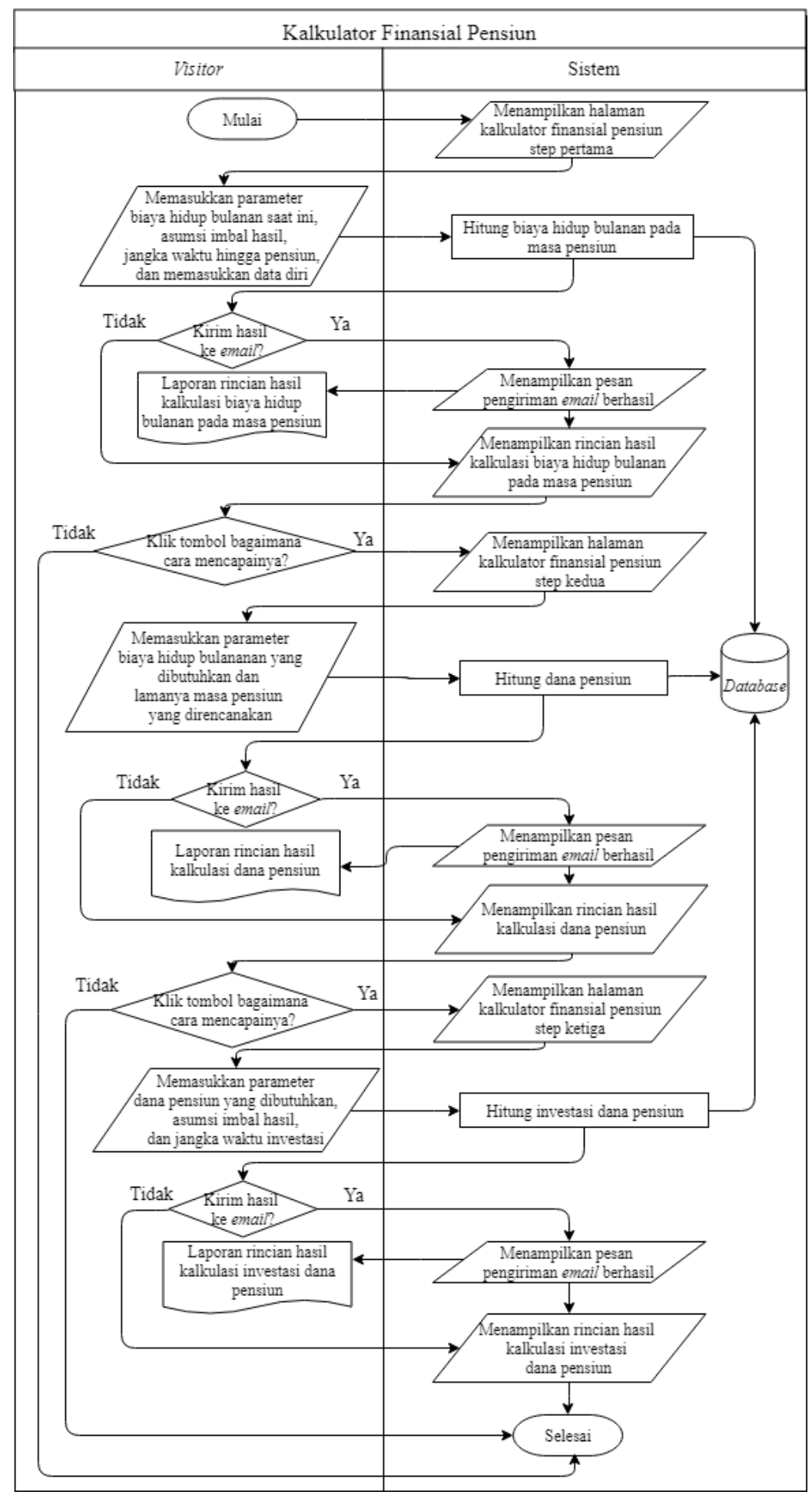

Gambar 3 Flowchart fase kedua

b Use case diagram

Perancangan use case diagram dalam pembuatan aplikasi Kalkulator Finansial Pendidikan dan Pensiun dibagi per subsistem, yakni subsistem kalkulator finansial pendidikan dapat dilihat pada Gambar 4 dan kalkulator finansial pensiun dapat dilihat pada Gambar 5. Aktor yang terlibat pada subsistem kalkulator fianansial pendidikan yaitu visitor. 


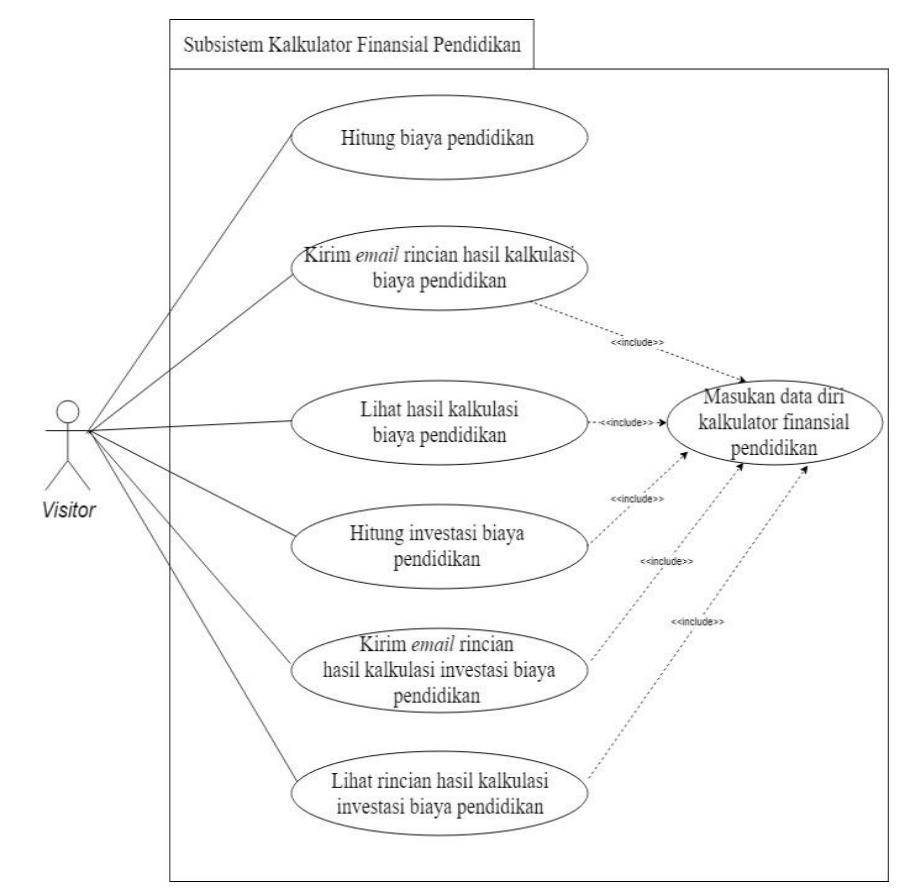

Gambar 4 Use case diagram kalkulator finansial pendidikan

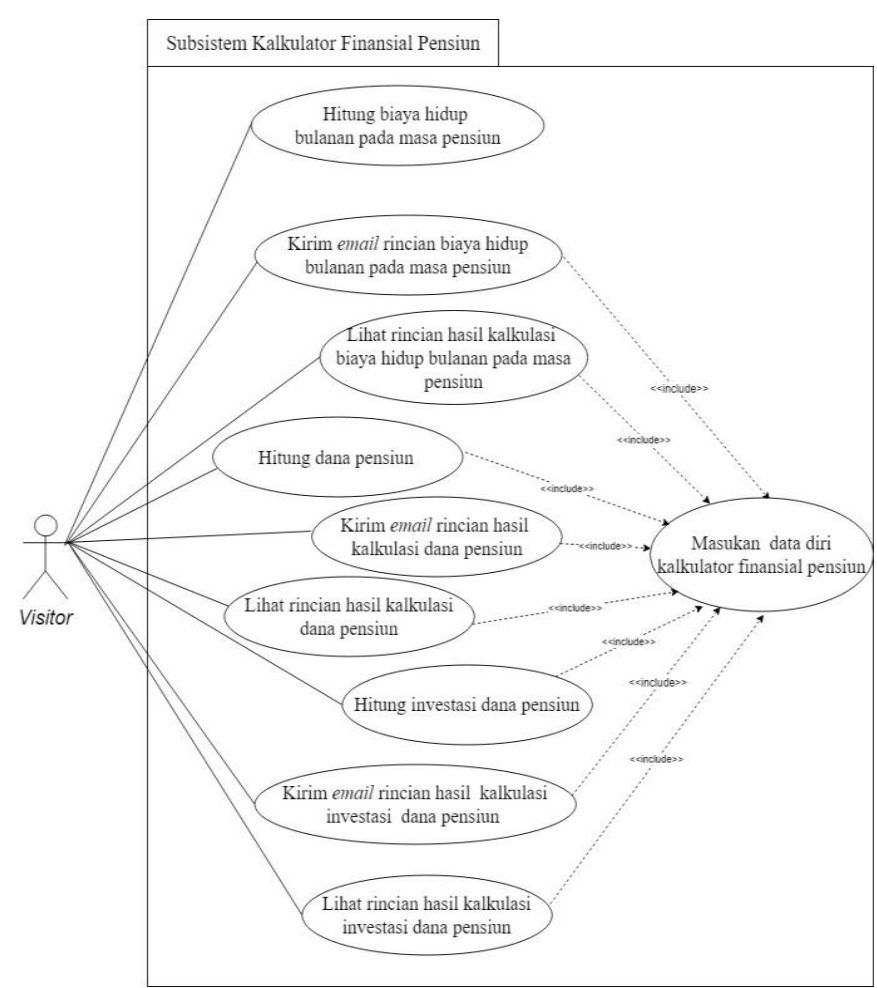

Gambar 5 Use case diagram kalkulator finansial pension

C

Class Diagram

Menurut Satzinger et al. (2012) Class diagram digunakan untuk menunjukkan class dari objek untuk sebuah sistem. Class yang berhubungan dengan kalkulator finansial pendidikan dan pensiun terdiri dari tiga class, yaitu 
class CalculatorType, class CalculatorLead dan class EmailBucket. Masingmasing class mempunyai atribut dan method. Class diagram kalkulator finansial pendidikan dan pensiun dapat dilihat pada Gambar 6 .
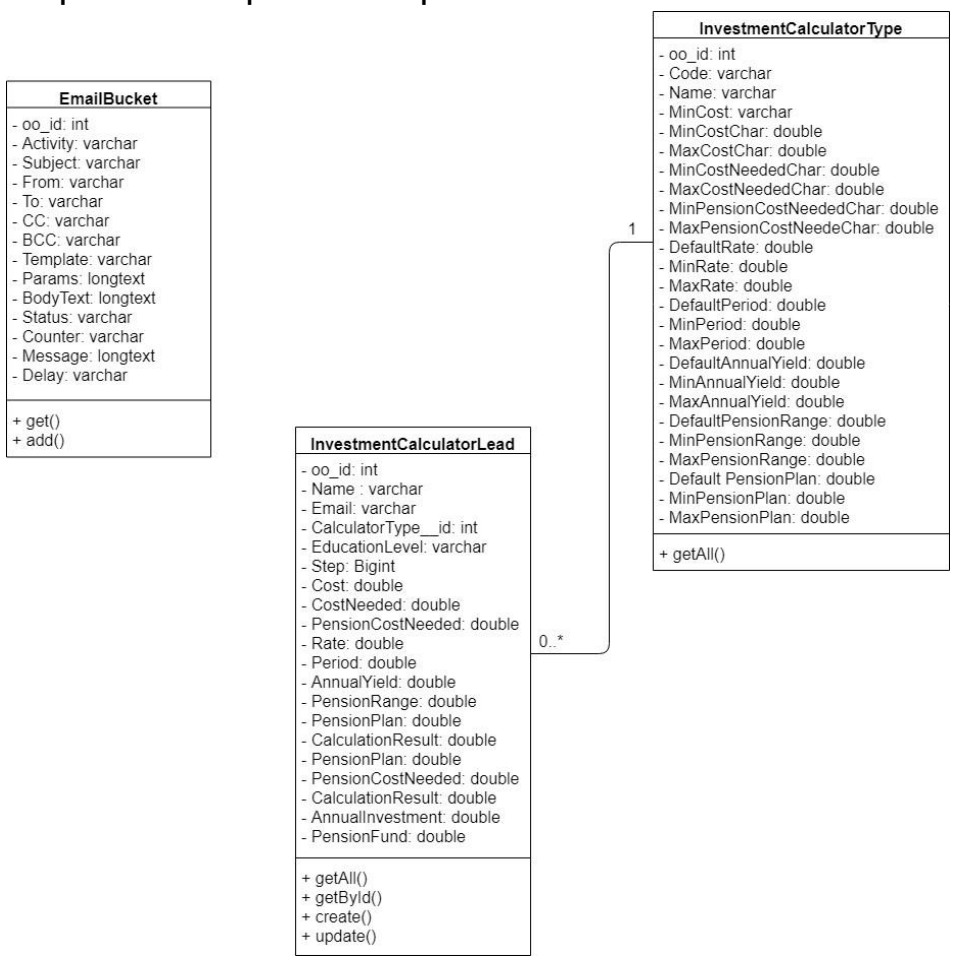

Gambar 6 Class Diagram

d Perancangan Database Structure

1) Tabel CalculatorType

Tabel CalculatorType adalah tabel basis data yang menyimpan rentang nilai parameter kalkulator finansial pendidikan dan pensiun.

2) Tabel CalculatorLead

Tabel CalculatorLead adalah tabel basis data yang menyimpan data masukan dan hasil kalkulasi kalkulator finansial pendidikan dan pensiun.

3) Tabel EmailBucket

Tabel EmailBucket adalah tabel basis data yang menyimpan data yang dikirim ke email.

2 Implementasi Database

Implementasi database dilakukan setelah melakukan perancangan data structure. Implementasi database dilakukan di CMS Pimcore. Database Management System (DBMS) yang digunakan yaitu MySQL

\section{Hitung Biaya Pendidikan}

Fungsi hitung biaya pendidikan merupakan fungsi yang terdapat pada kalkulator finansial pendidikan step pertama. Fungsi ini untuk menghitung biaya pendidikan yang dibutuhkan pada masa depan. Parameter yang harus dimasukkan visitor meliputi jenjang pendidikan, biaya pendidikan saat ini, asumsi tingkat inflasi, dan jangka waktu investasi. Alur aktivitas yang menggambarkan 
proses hitung biaya pendidikan dapat dilihat pada Gambar 7. Antarmuka fungsi hitung biaya pendidikan dapat dilihat pada Gambar 8 .

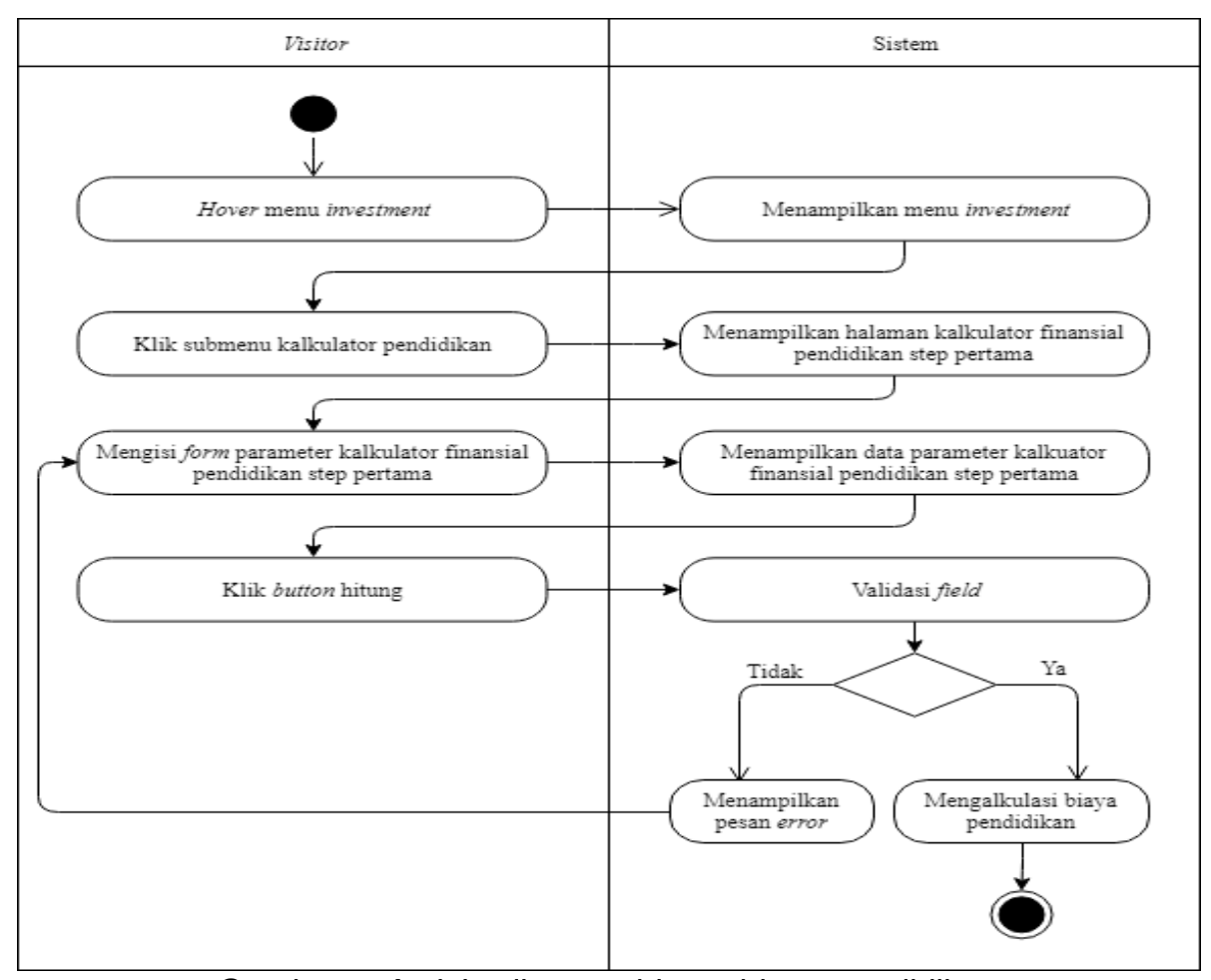

Gambar 7 Activity diagram hitung biaya pendidikan

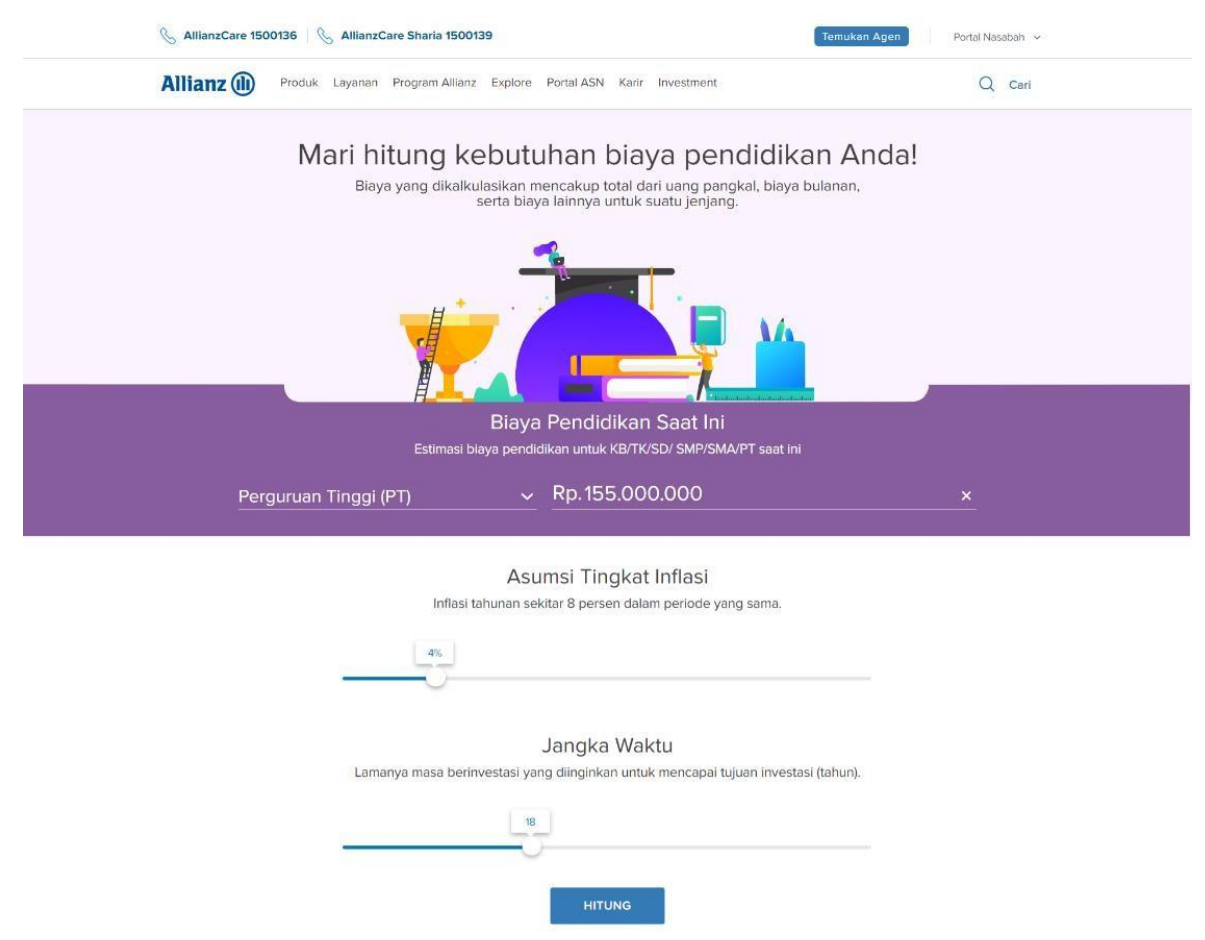

Gambar 8 Antarmuka fungsi hitung biaya pendidikan 
4 Masukan Data Diri Kalkulator Finansial Pendidikan

Fungsi masukan data diri kalkulator finansial pendidikan merupakan fungsi yang terdapat pada kalkulator finansial pendidikan step pertama. Visitor wajib mengisi form data diri yang meliputi nama dan alamat email.

5 Kirim Email Rincian Hasil Kalkulasi Biaya Pendidikan

Fungsi kirim email rincian hasil kalkulasi biaya pendidikan merupakan fungsi yang terdapat pada kalkulator finansial pendidikan step pertama. Visitor dapat mengirim rincian hasil kalkulasi biaya pendidikan yang dibutuhkan melalui email jika telah menekan checkbox Kirimkan hasil perhitungan ke email saya pada pop up data diri.

6 Lihat Rincian Hasil Kalkulasi Biaya Pendidikan

Fungsi lihat rincian hasil kalkulasi biaya pendidikan merupakan fungsi yang ada pada kalkulator finansial pendidikan step pertama. Pada fungsi ini visitor dapat melihat rincian hasil kalkulasi biaya pendidikan yang dibutuhkan pada masa depan.

7 Hitung Investasi Biaya Pendidikan

Fungsi hitung investasi biaya pendidikan merupakan fungsi yang terdapat pada kalkulator finansial pendidikan step kedua. Fungsi ini, untuk menghitung investasi biaya pendidikan yang dibutuhkan per tahun dan per bulan untuk mencapai biaya pendidikan yang dibutuhkan. Parameter yang harus dimasukkan visitor meliputi biaya pendidikan yang dibutuhkan dan asumsi imbal hasil.

8 Kirim Email Rincian Hasil Kalkulasi Investasi Biaya Pendidikan

Fungsi kirim email rincian hasil kalkulasi investasi biaya pendidikan merupakan fungsi yang terdapat pada kalkulator finansial pendidikan step kedua. Visitor dapat mengirim rincian hasil kalkulasi investasi biaya pendidikan melalui email, jika telah menekan checkbox Kirimkan hasil perhitungan ke email saya.

9 Lihat Rincian Hasil Kalkulasi Investasi Biaya Pendidikan

Fungsi lihat rincian hasil kalkulasi investasi biaya pendidikan merupakan fungsi yang ada pada kalkulator finansial pendidikan step kedua. Pada fungsi ini visitor dapat melihat rincian hasil kalkulasi investasi biaya pendidikan per tahun dan per bulan untuk mencapai biaya pendidikan yang dibutuhkan.

\section{Sprint Review}

Tahap sprint review pada sprint pertama tim pengembang programmer menjelaskan dan menampilkan semua pekerjaan yang telah dikerjakan sesuai dengan sprint goal. Sprint backlog yang telah diselesaikan oleh tim pengembang programmer pada sprint pertama kemudian dilakukan pengujian oleh Quality Assurance PT Gerbang Indonesia Teknologi. 


\section{E Sprint Retrospective}

Pada tahap ini tim pengembang berdiskusi untuk membahas kekurangan dan kendala yang dialami pada sprint pertama. Pada sprint pertama tim pengembang programmer terdapat kendala berupa kesulitan dalam mengimplementasikan framework symfony dan CMS Pimcore. Solusi yang dilakukan adalah mempelajari dokumentasi tentang framework symfony dan CMS Pimcore.

\subsection{Sprint Kedua}

Fungsi yang dibangun pada sprint kedua yaitu fungsi-fungsi untuk kalkulator finansial pensiun dan admin dapat mengedit rentang nilai parameter pada kalkulator pendidikan dan pensiun menggunakan CMS Pimcore.

\section{A Sprint Planning}

Sprint planning merupakan acara pembukaan dalam rangkaian sprint. Proses sprint planning pada sprint kedua ini menetapkan sprint goal dan sprint backlog yang akan dikerjakan pada sprint kedua. Sprint backlog berisi sekumpulan product backlog item dan task yang harus dikerjakan oleh tim pengembang programmer pada sprint kedua. Sprint backlog pada sprint pertama mengerjakan product backlog item poin 11 sampai 22.

\section{B Daily Scrum}

Daily scrum pada sprint kedua di hadiri oleh tim pengembang dan scrum master. Acara ini dilakukan setiap hari dengan durasi 15-20 menit. Acara ini bertujuan untuk meninjau perkembangan sprint goal dan melakukan sinkronisasi pekerjaan masing-masing pada sprint kedua.

\section{Development}

Proses development pada sprint kedua mengerjakan sekumpulan task yang ada pada sprint backlog agar tercapai sprint goal pada sprint kedua. Berikut adalah pekerjaan yang telah dikerjakan tim pengembang programmer pada proses development:

1 Hitung Biaya Hidup Bulanan pada Masa Pensiun

Fungi hitung biaya hidup bulanan pada masa pensiun merupakan fungsi yang terdapat pada kalkulator finansial pensiun step pertama. Fungsi ini, untuk menghitung biaya hidup bulanan pada masa pensiun. Parameter yang harus dimasukkan visitor meliputi biaya hidup bulanan saat ini, asumsi tingkat inflasi, dan jangka waktu hingga pensiun.

2 Masukan Data Diri Kalkulator Finansial Pensiun

Fungsi masukan data diri kalkulator finansial pensiun merupakan fungsi yang terdapat pada kalkulator finansial pensiun step pertama. Visitor wajib mengisi form data diri yang meliputi nama dan alamat email.

3 Kirim Email Rincian Hasil Kalkulasi Biaya Hidup Bulanan pada Masa Pensiun

Fungsi kirim email rincian hasil kalkulasi biaya hidup bulanan pada masa pensiun merupakan fungsi yang terdapat pada kalkulator finansial pensiun step 
pertama. Visitor dapat mengirim rincian hasil kalkulasi biaya hidup bulanan pada masa pensiun melalui email, jika telah menekan checkbox Kirimkan hasil perhitungan ke email saya pada pop up data diri.

4 Lihat Rincian Hasil Kalkulasi Biaya Hidup Bulanan pada Masa Pensiun

Fungsi lihat rincian hasil kalkulasi biaya hidup bulanan pada masa pension merupakan fungsi yang ada pada kalkulator finansial pensiun step pertama. Pada fungsi ini visitor dapat melihat rincian hasil kalkulasi biaya hidup bulanan pada masa pensiun.

$5 \quad$ Hitung Dana Pensiun

Fungsi hitung dana pensiun merupakan fungsi yang terdapat pada kalkulator finansial pensiun step kedua. Fungsi ini, untuk menghitung dana pensiun yang dibutuhkan untuk mencapai biaya hidup bulanan pada masa pensiun. Parameter yang harus dimasukkan oleh visitor meliputi biaya hidup bulanan yang dibutuhkan dan lamanya masa pensiun yang direncanakan.

6 Kirim Email Rincian Hasil Kalkulasi Dana Pensiun

Fungsi kirim email rincian hasil kalkulasi dana pensiun merupakan fungsi yang terdapat pada kalkulator finansial pensiun step kedua. Visitor dapat mengirim rincian hasil kalkulasi dana pensiun melalui email, jika telah menekan checkbox Kirimkan hasil perhitungan ke email saya.

7 Lihat Rincian Hasil Kalkulasi Dana Pensiun

Fungsi lihat rincian hasil kalkulasi dana pensiun merupakan fungsi yang ada pada kalkulator finansial pensiun step kedua. Pada fungsi ini visitor dapat melihat rincian hasil kalkulasi dana pensiun untuk mencapai biaya hidup bulanan pada masa pensiun.

8 Hitung Investasi Dana Pensiun

Fungsi hitung investasi dana pensiun merupakan fungsi yang terdapat pada kalkulator finansial pensiun step ketiga. Fungsi ini, digunakan untuk menghitung investasi dana pensiun per tahun dan per bulan untuk mencapai dana pensiun yang dibutuhkan. Parameter yang harus dimasukkan visitor meliputi dana pensiun yang dibutuhkan, asumsi imbal hasil, dan jangka waktu investasi.

9 Kirim Email Rincian Hasil Kalkulasi Investasi Dana Pensiun

Fungsi kirim email rincian hasil kalkulasi investasi dana pesiun merupakan fungsi yang terdapat pada kalkulator finansial pensiun step ketiga. Visitor dapat mengirim rincian hasil kalkulasi investasi dana pensiun ke email, jika telah menekan checkbox Kirimkan hasil perhitungan ke email saya.

10 Lihat Rincian Hasil Kalkulasi Investasi Dana Pensiun

Fungsi lihat rincian hasil kalkulasi investasi dana pensiun merupakan fungsi yang ada pada kalkulator finansial pensiun step ketiga. Pada fungsi ini visitor dapat melihat rincian hasil kalkulasi investasi dana pensiun untuk mencapai dana pensiun yang dibutuhkan.

11 Edit rentang nilai parameter kalkulator pendidikan di pimcore

Fungsi ini, digunakan untuk mengedit rentang nilai parameter yang terdapat pada kalkulator finansial pendidikan. Aktivitas edit rentang nilai dilakukan oleh admin menggunakan CMS Pimcore. Data parameter yang diedit menggunakan CMS Pimcore disimpan ke database, kemudian hasil perubahan 
nilai parameter ditampilkan pada halaman web kalkulator finansial pendidikan.

12 Edit rentang nilai parameter kalkulator pensiun dipimcore

Fungsi ini, digunakan untuk mengedit rentang nilai parameter yang terdapat pada kalkulator finansial pensiun. Aktivitas edit rentang nilai dilakukan oleh admin dengan menggunakan CMS Pimcore. Data parameter yang diedit menggunakan CMS Pimcore disimpan ke database, kemudian hasil perubahan nilai parameter ditampilkan pada halaman web kalkulator finansial pensiun.

\section{Sprint Review}

Tahap sprint review pada sprint kedua tim pengembang programmer menjelaskan dan menampilkan semua pekerjaan yang telah dikerjakan sesuai dengan sprint goal. Sprint backlog yang telah diselesaikan oleh tim pengembang programmer pada sprint kedua kemudian dilakukan pengujian oleh Quality Assurance PT Gerbang Indonesia Teknologi.

\section{E Sprint Retrospective}

Sprint Retrospective pada sprint kedua, tim pengembang hanya melakukan review kinerja selama masa pembuatan aplikasi Kalkulator Finansial Pendidikan dan Pensiun. Tim pengembang programmer telah melaksanakan tugasnya dengan baik. Tim pengembang programmer juga telah menerapkan perbaikan dari sprint retrospective pada sprint sebelumnya.

\section{Demo}

Pada tahap ini, tim pengembang melakukan demo aplikasi secara keseluruhan kepada product owner bersama scrum master. Demo berupa fiturfitur yang telah diselesaikan sesuai dengan waktu yang telah ditetapkan. Aplikasi Kalkulator Finansial Pendidikan dan Pensiun berhasil dirilis dengan fitur sebagai berikut :

$1 \quad$ Kalkulasi biaya pendidikan yang dibutuhkan.

2 Kalkulasi investasi biaya pendidikan yang dibutuhkan.

$3 \quad$ Kalkulasi biaya hidup bulanan pada masa pensiun.

$4 \quad$ Kalkulasi dana pensiun yang dibutuhkan.

5 Kalkulasi investasi dana pensiun yang dibutuhkan.

6 Kirim email hasil kalkulasi pada kalkulator finansial pendidikan dan pensiun.

\section{SIMPULAN}

Aplikasi Kalkulator Finansial Pendidikan dan Pensiun pada Website Allianz.co.id di PT Gerbang Indonesia Teknologi ini telah dibuat dengan menyediakan fitur-fitur :

$1 \quad$ Kalkulasi biaya pendidikan yang dibutuhkan.

2 Kalkulasi investasi biaya pendidikan yang dibutuhkan.

$3 \quad$ Kalkulasi biaya hidup bulanan pada masa pensiun.

$4 \quad$ Kalkulasi dana pensiun yang dibutuhkan. 
$5 \quad$ Kalkulasi investasi dana pensiun yang dibutuhkan.

6 Kirim email hasil kalkulasi pada kalkulator finansial pendidikan dan pensiun

\section{SARAN}

Aplikasi Kalkulator Finansial Pendidikan dan Pensiun memiliki kekurangan dalam validasi alamat email. Validasi alamat email pada aplikasi ini menggunakan format penulisan alamat email yaitu

recipentname@domainname.topleveldomain. Kelemahan menggunakan validasi ini yaitu, jika visitor memasukan alamat email yang belum terdaftar dengan format penulisan alamat email benar, data akan tetap masuk ke database. Rekomendasi pengembangan aplikasi ini yaitu dengan menambahkan validasi pengecekan bahwa alamat email yang dimasukkan harus sudah terdaftar, dengan demikian dapat meminimalisir kesalahan penulisan alamat email serta rincian hasil kalkulasi benar-benar dikirim pada alamat email yang sudah terdaftar.

\section{DAFTAR PUSTAKA}

Anhar. 2010. Panduan Menguasai PHP \& MySQL Secara Otodidak. Jakarta(ID): mediakita.

Enterprise J. 2015. Step by Step HTML 5. Jakarta(ID): PT Elex Media Komputindo.

Indrajani. 2015. Database Design. Jakarta(ID): PT Elex Media Komputindo.

Koesheryatin, Suryana T. 2014. Aplikasi Internet Menggunakan HTML, CSS, \& JavaScript. Jakarta(ID): PT Elex Media Komputindo

Nugroho A. 2010. Rekayasa Perangkat Lunak Berorientasi Objek dengan Metode USDP. Yogyakarta(ID): CV Andi Offset.

Partogi J. 2015. Manajemen Modern dengan SRUM. Yogyakarta(ID): ANDI. Porebski B, Przystalski K, Nowak L. 2011. Building PHP Applications with

Symfony ${ }^{\mathrm{TM}}$, CakePHP, and Zend® Framework. Canada: Wiley Publishing, Inc.

Pressman RS. 2010. Software Engineering: A Practitioner's Approach Seventh Edition. New York(USA): McGraw-Hill.

Satzinger JW, Jackson RB, Burd SD. 2012. System Analysis and Design in a Changing World Sixth Edition. Boston(USA): Course Technology.

Schwaber K, Sutherland J. 2017. The Scrum Guide. [internet]. [diunduh 18 Februari 2019]. Tersedia pada:http://www.scrumguides.org/scrumguide.html.

Wardana. 2016. Aplikasi Website Profesional dengan PHP dan jQuery.Jakarta(ID): PT Elex Media Komputindo. 